\title{
Effect of aquatic therapy exercises with and without the use of Jacuzzi on the lower limb strength and the quality of life in elderly women
}

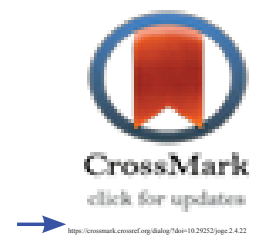

\author{
*Karami Sh${ }^{1}$, Tadibi $\mathrm{V}^{2}$
}

1- MSc (Corrective Exercise and Sport Injuries), Faculty of Humanities, Islamic Azad University of Brujerd, Brujerd, Iran (Corresponding Author)

Email: Shimakarami76@yahoo.com

2- PhD, Associate Professor, Department of Sport Physiology, Faculty of Physical Education \& sport sciences, Razi Kermanshah University, Kermanshah, Iran.

\section{Abstract}

Introduction: Problems associated with decreased muscle strength and subsequently diminished quality of life, will be increased by aging. Therefore, elderly people will expose to serious injuries. So the aim of this study was to investigate the effect of 8 weeks aquatic therapy exercises with and without Jacuzzi on lower limb strength and quality of life in elderly women.

Method: This study was performed with a pretest-post-test randomized-group design. Thirty six women aged 65-74 years old, participated in the study voluntarily. Participants randomly assigned into 3 groups that each of themcontained 12 elderly women, including control, aquatic therapy, and aquatic therapy with Jacuzzi groups. The $30 \mathrm{sec}$ chair stand test and Sf-36 Questionnaire were used to measure lower limb strength and Quality of Life, respectively. ANOVA with repeated measures, independent t-test, and paired-t test were used to statistical analysis with SPSS software version 22 .

Results: After the interventions, strength of the lower limbs had significant increases in the aquatic therapy groups without $(p=.000)$ and with Jacuzzi $(p=.000)$, However there was no significant change in the control group $(\mathrm{p}=.724)$. Physical health improved significantly in the aquatic therapy groups without $(p=.000)$ and with Jacuzzi $(p=.000)$, but not in the control group $(p=.066)$. Also mental health increased significantly in the aquatic therapy groups without $(p=.000)$ and with Jacuzzi $(p=.000)$, and decreased significantly in the control group $(p=.005)$.

Conclusion: Performing three sessions of aquatic therapy per week for 8 weeks with or without the use of Jacuzzi, have a positive and significant effect on the muscular strength of the lower limbs and the quality of life in the elderly women.

Key Words: Hydrotherapy, Muscle strength, Quality of life, Eldery women.

Received: 6 December 2017

Accepted: 26 April 2018

\begin{tabular}{|l|l|}
\hline \multicolumn{3}{|c|}{ Access this article online } \\
\hline Website: \\
\hline Www.joge.ir
\end{tabular}




\title{
تأثير تمرينات آب درمانى با و بدون جكوزى بر قدرت اندام تحتانى و كيفيت زندكى زنان سالمند
}

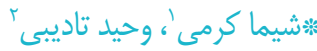

إ-كارشناس ارشد آسيبشناسى ورزشى و حركات اصلاحى، دانشكده علوم انسانى، دانشعاه آزاد اسلامى، واحد بروجرد، بروجره، ايران (نويسنده مسئول) يست الكترونيكى: shimakaramivя@yahoo.com r- دانشيار كروه فيزيولوزى ورزشى، دانشكده تربيت بدنى، دانشكاه رازى كرمانشاه، كرمانشاه، ايران.

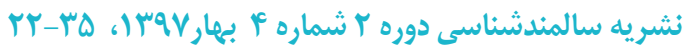

مقدمه: با افزايش سن، مشكلات مرتبط با كاهش قدرت عضلانى و به دنبال آن كاهش كيفيت زندكى افراد افز ايش مي يابد. بنابر اين

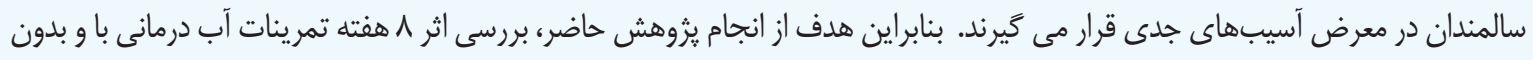

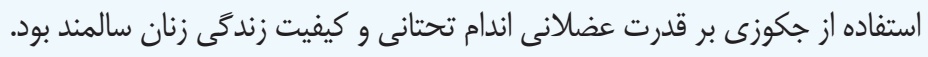

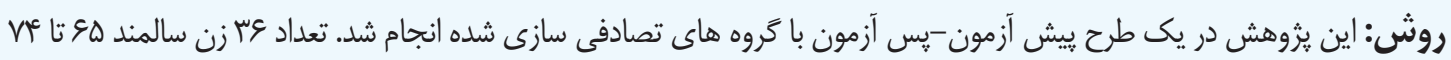

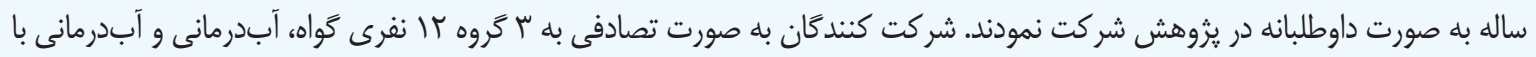

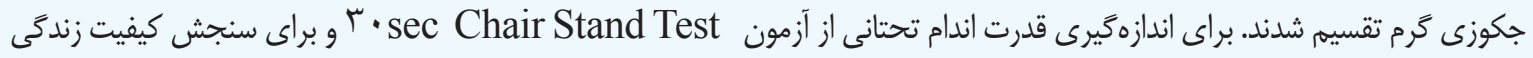

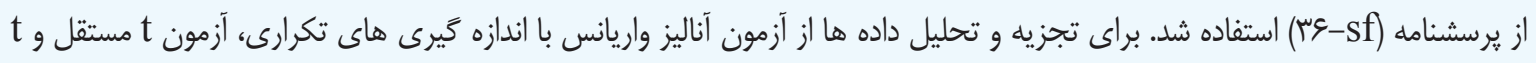

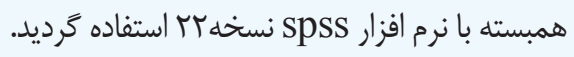

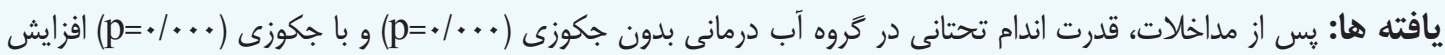

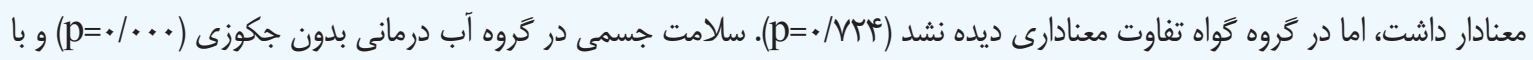

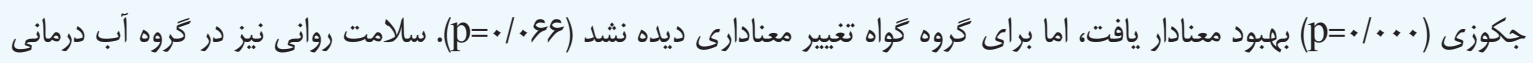

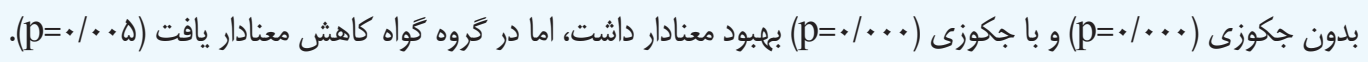
نتيجه كَيرى: انجام سه وهله آب درمانى در هفته به مدت 1 هفته باو بدون استفاده از جكوزى، هر دو بر قدرت عضلانى اندام تحتانى

$$
\text { و كيفيت زندگى زنان سالمند اثر مثبت و معنادارى دارد. }
$$

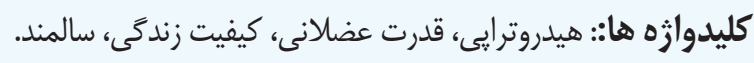


و عملكرد اجتماعى براى زندگى مستقل، از اهداف نظام سلامتى هر

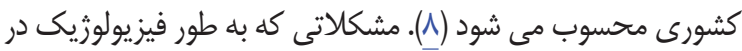

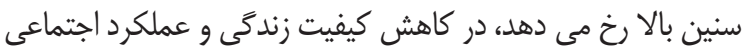
در طول دوره سالمندى تأثير دارند (ج).

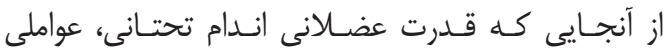
تـاثير كَذار در قابليـت حركتـى و كنتــل سلامت افراد سـالمند

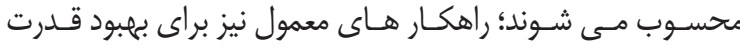
عضـلانى، تحـرك و قابليـت حركتى افر اد سالمند، استفاده از وسايل كمكى مانند عصا، واكر و برنامه ى تمرينى است (ه).

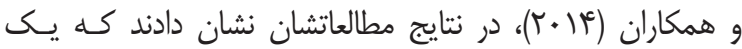
برنامه منظهم ورزشى به ميزان قابل توجهى باعث افزايش قـدرت

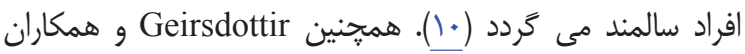
(ها +r)، به اين نتيجه رسيدند كه تمرينات مقاومتى باعث افزايش قدرت عضلانى و عملكرد فيزيكى افراد سالمند مى شود (II). بـا وجـود اينكه نتايج تحقيقات مختلف، نشان دهنده مز ايـاى اجـراى

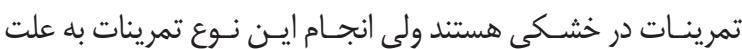
برخى مسـائل روانسى و بـدنى حاصـل از افزايش و كهولت سن،

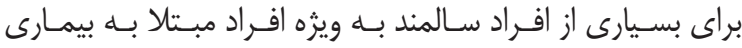

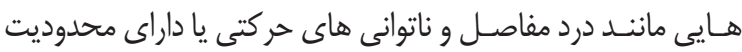
هاى فيزيولوزيكى و أناتوميكى، مناسب نيست (T) (I). از جمله روشهاى تمرينى كه در سالهاى اخير مورد توجه

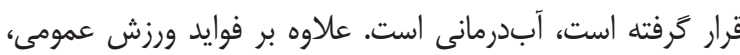
آب درمانى فوايد فيزيولوزيكى و فيزيكى منحصر به فردى را اعمال مى كند. جريان آب، وزن و فشار بر مفاصل را كاهش دادئ داده و آزادى حركت را ايجاد مى كند. به خاطر ويثگى شناورى آب دامنه حركت

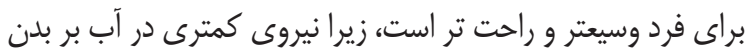

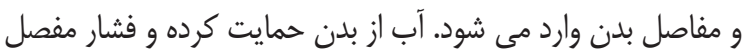
را كاهش مىدهد و حمايت و مقاومت را براى حركت فراهم كرده و امكان حركت و قدرت عمل را توسعه مىدهد (با). بنابر اين محيط

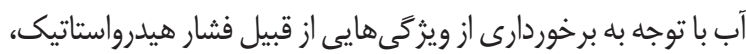

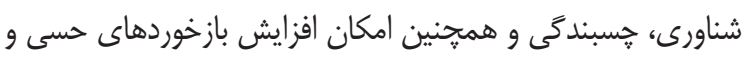
حس عمقى، مىتواند محيطى مناسب براى انجام تمرينات بدنى

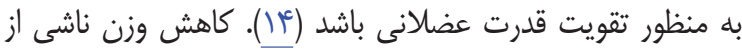

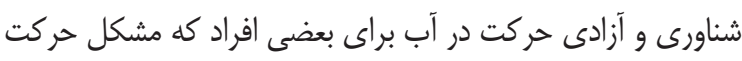
روى زمين دارند، علاوه بر منافع روحى، فوايد جسمى زيادى نيز بوجود مى آورد. اين مطلب بهخصوص در سالمندان حائز اهميت است.

انجام بسيارى از حركات كه در سنين ميانسالى و كهنسالى در خشكى
Aoväo

طبق تعريف سازمان بهداشت جهانى از سالمندى، زمانى كه فرد به سن •9 سالكى مى رسل، سالمند تلقى مى شوند ((). فرايند سـالمندى را مسى تـوان مجموعه اى از تغييرات نـامطلوب لهاب

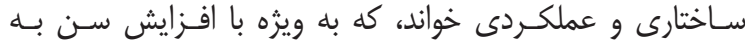
صـورت فزاينـده اى روى هم انباشته مى شوند. ايـن تغييـرات

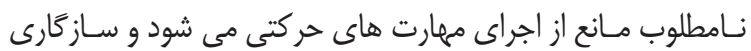

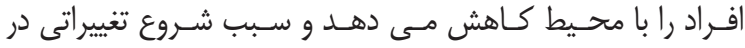

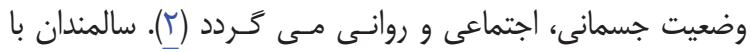
مشكلات و فقدان هاى متعددى در اين دوران مواجه بوده و تغييرات بيشترى نسبت به ساير دوران عمر تجربه مى كنند كه از جمله آنها

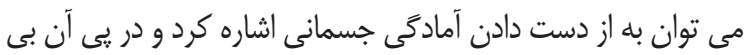

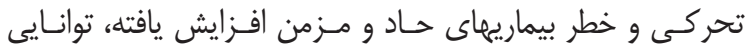
هـاى عملكـردى افراد و قدرت عضلانى آنها كاهش مى ئى يابد (ِّ).

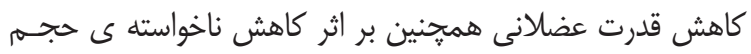
عضـالات اسـكلتى (از يديده هاى شايع افزايش سن) نيز اتفاق

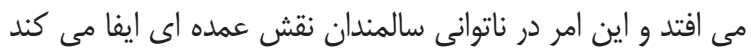

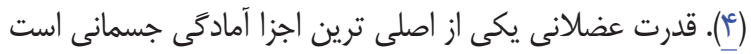
كه كاهش آن منجر به محدوديت هاى حركتى و ايجاد مشكلاتى آنى إنى

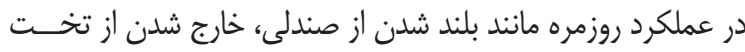

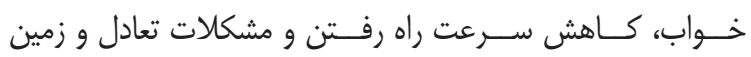
خوردن مى كر دد (ه) كه به علت محـدوديتهـاى حركتى، استقالال افراد سالمند و كيفيت زندگى آنها كـاهش و وابستخى آنها افزايش مى يابد و باعث نيازمندى فـرد سـالمند به حمايت هاى روزافزون

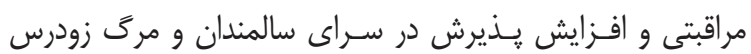

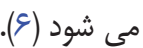

ضعف عضلانى در اندام هاى تحتانى سالمندان با خطر افتادن هنخام حركت و راه رفتن در ارتباط است. علاوه براين، توانايى ايجاد

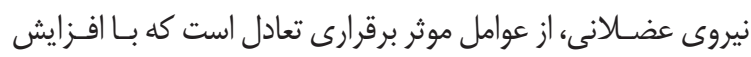
سـن، كمم تحركى و تأثير بيمارى ها كاهش مى يابد؛ و از اين

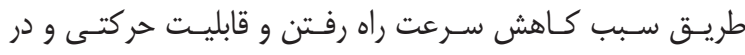
نتيجه، افزايش خطر زمين خوردن مى شود و فعاليت هاى روزمره را

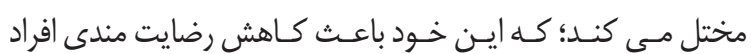
سالمند از زندگى و كيفيت زندگى آنها مى شود (؟). كيفيت زندَّى

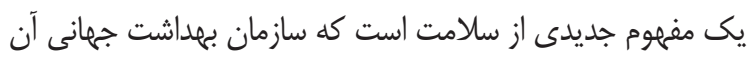

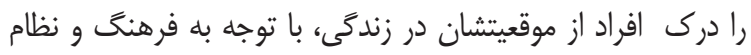

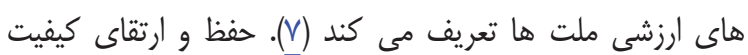
زندگى سالمندان، كاهش اثر بيماريهاى مزمن و ارتقاى سطح توانايى 
آب درمانى، همجنين مزيت هاى احتمالى كه آب درمانى همراه با

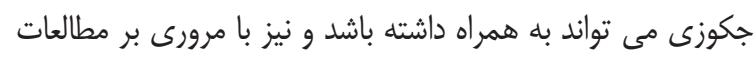
قبلى مشخص شد كه در خصوص تاثير آبدرمانى باو بدون استفاده از جكوزى بر قدرت عضلانى و كيفيت زندگى سالمندان، مطالعه اى انجام نشده است. از اين رو اين تحقيق با هدف بررسى اثر تمرينات

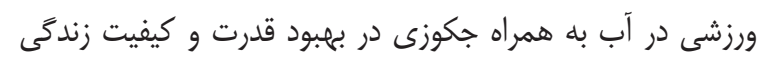

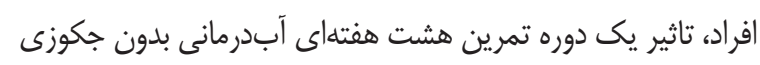

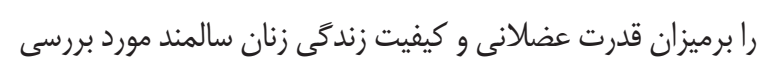

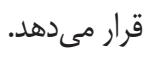

\section{و ش}

جامعه آمارى يثوهش حاضر را زنان سالمند ه\& تا ع Vال سال

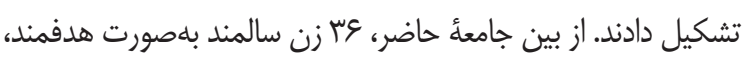
انتخاب شدند و سيس بلصورت تصادفى ساده، به س گروه ז

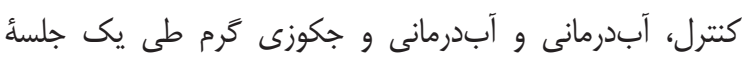
توجيهى و آشنايى، تقسيهم شدند. در ابتدا از تمامى آزمودنى ها خواسته

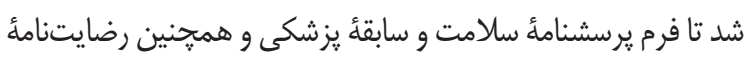
شركت در آزمون را قبل از شركت در يروهش، تكميل و امضا نمايند.

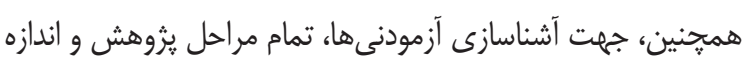

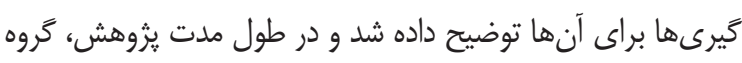
تجربى بلجز يروتكل تمرينى، از هيج نوع مدل تمرينى ديخر استفاده نكردند.

معيارهاى ورود به يزوهش عبارت بودند از: ا. نداشتن سابقه تمرينى آبدرمانى r. توانايى انجام مستقل فعاليتهاى روزمره س.

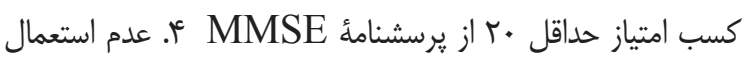
مواد مخدر و مواد الكلى ه. عدم سابقهُ شكستخىى، دررفتخى يا آسيب

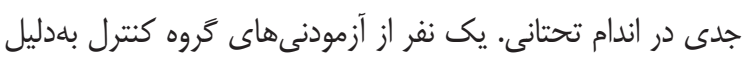

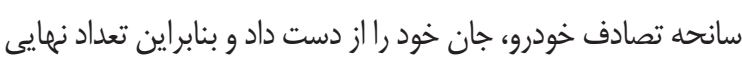
آزمودنى هاى اين گروه، ال النفر بود.

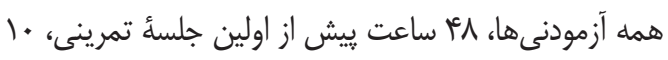

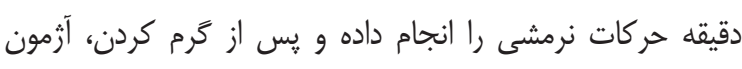

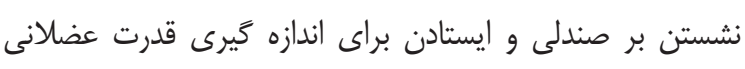

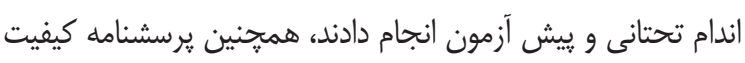

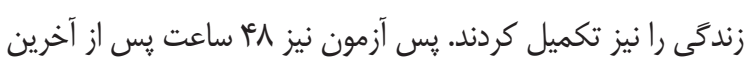

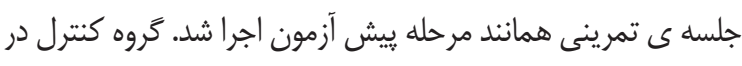
مدت 1 هفته، هيج گَونه فعاليت ورزشى منظمى انجام ندادند و صرفا فعاليتهاى روزمره خود را دنبال كردند. اندازه گيرى كيفيت زندگى رؤى
به زحمت صورت مى گيرد؛ در آب به سهولت انجاميذير است و افراد قادرند با شدت كمترى نسبت به خشكى، حر كات را انجام دهند. از اين رو ورزش در آب و ارزشهاى درمانى آن در جمعيت سالمند مورد

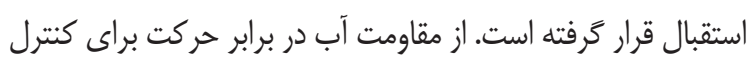
تغيير سرعت حركت و باز آموزى عضلات استفاده شده است (ها). Fernanda مبتلا به يوكى استخوان نشان دادند كه تمرينات آب درمانى بر بهبود عملكرد فيزيكى و قدرت عضلانى اين افراد تاثير مثبت دارد (عال). Ashley

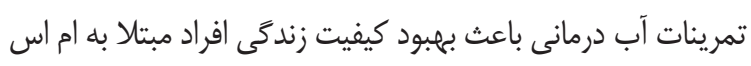

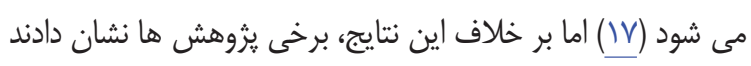

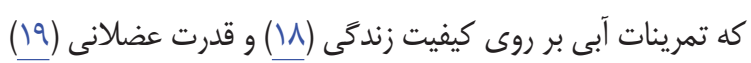
تاثير ندارد. در ايران هم كامرانى فراز و همكاران (هوسا)، در تحقيقى

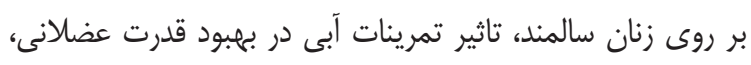
انعطاف يذيرى و كيفيت زندكَى زنان سالمند را به اثبات رساندند (ه). همجنين ميرزاييان و همكاران (هوسا)، در يثوهشى به اين نتيجه رسيدند كه اثر تمرين در آب بر تعادل ايستاو يويا، راه رفتن و قدرت اندام تحتانى زنان سالمند موثر است (•r).

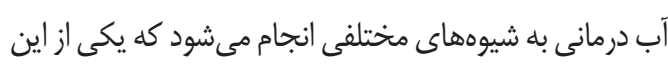
شيوهها استفاده از جكوزى است. از نظر تجربى دريافتهاند سالمندان براى استفاده از جكوزى رغبت دارند و همواره قبل و بعد از تمرين تمايل به استفاده از جكوزى را دارند. برخى يثوهشهای جاى سودمند

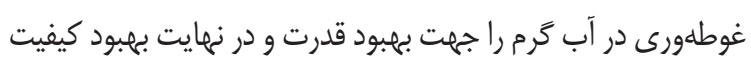

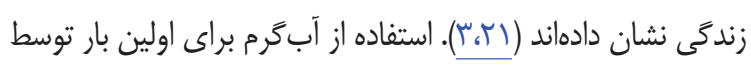

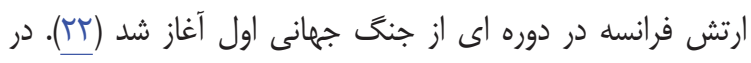

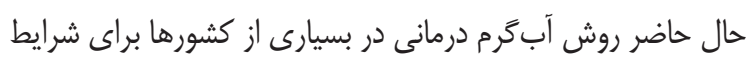
يزشكى و جراحى به عنوان يك درمان استفاده مىشود. آب گرم

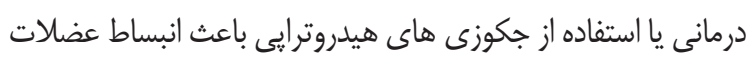

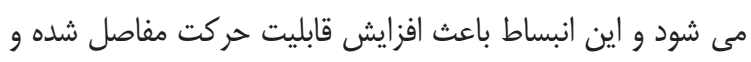

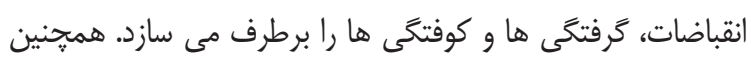

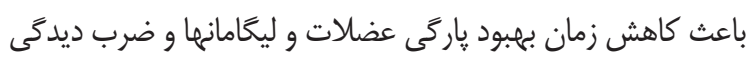

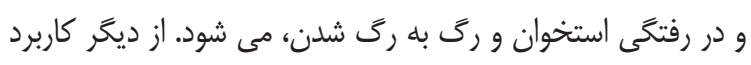

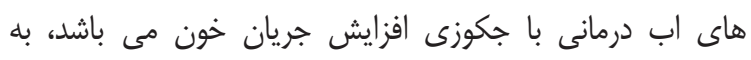
اين صورت كه جريان خون بلدون بالا رفتن ضربان قلب افزايش جان جان

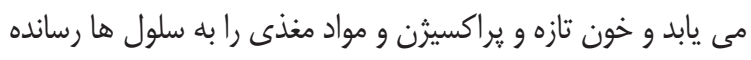

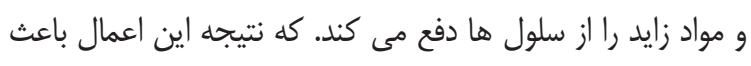
تقويت جريان لنف در بدن، برقرارى تعادل در محلول هاى بدن

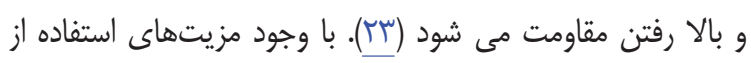


به وضوح در زاويه بيشتر از •و درجه خم شده باشند بنابراين ياشنه

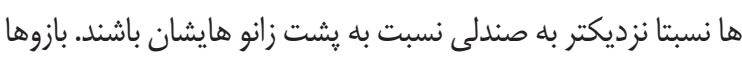
از مج دست ضربدرى قرار گيرند و نزديك به قفسه سينه قرار گيرند. آزمايشكر جهت ايمنى نزديك به صندلى مى ايستد بنابر اين ميتواند

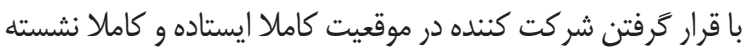

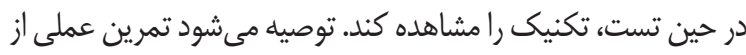

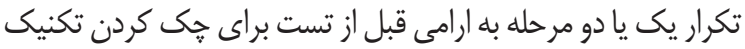

$$
\text { و فهم آن صورت كيرد. }
$$

شركت كننده از موقعيت نشسته برخاسته و كاملا مى ايستد، بنابراين مفاصل ران و زانو ها بطور كامل از صندلى جدا مى شوند،

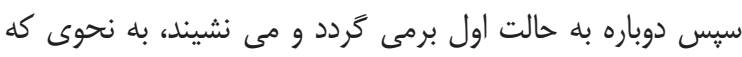

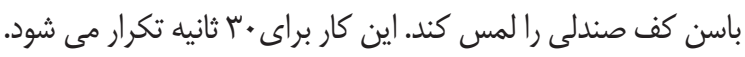

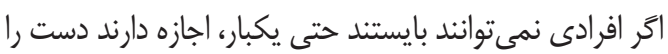
بر روى قاهاى خود قرار داده و يا از وسايل كمكى شان در حركت (واكر وبلحرو..) بطور ضابطه مند استفاده كنند.

$$
\text { دستورات شفاهى: }
$$

براى اين تست، انجام دادن هر هه سريع تر حركت مناسب

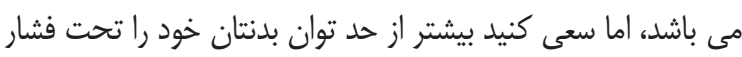
قرار ندهيد تا دجار آسيب ديدگى نشويد.

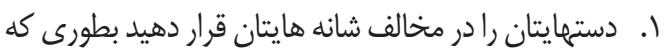
بازوهاى شما از مج دست ضربدرى قرار گيرند ونزديك درميان قفسه

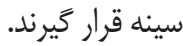
ז. . باهايتان را صاف بر زمين و به اندازه ع عرض شانه باز از هم نكخه داريد. r. با علامتى براى شروع، به يك موقعيت كاملا ايستاده

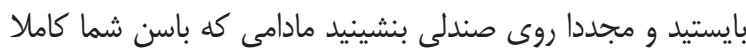
كف صندلى را لمس كند. F. . براى •ب ثانيه و تا زمان اعلام كلمه توقف ادامه دهيد.

$$
\begin{aligned}
& \text { ه. آماده باشيد و شروع كنيد. } \\
& \text { امتياز دهى: }
\end{aligned}
$$

با علامتى براى شروع، شروع ساعت تايمردار زده شده و تعداد كل ايستادن ها بر روى صندلى در سى ثانيه شمارش كرديد. (بالاو و

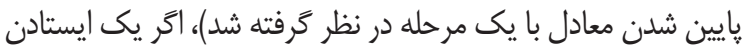

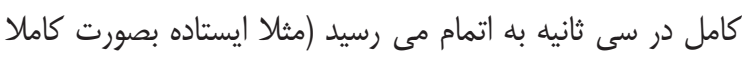

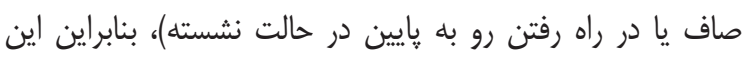
ايستادن كامل در مجموع مورد شمارش قرار كرفت. شركت كننده ها مى توانستند در صورت خسته شدن بايستند

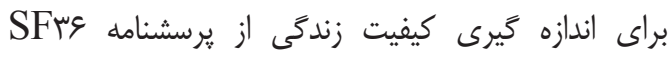

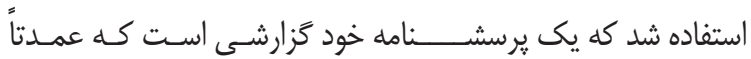
جهـت بررسى كيفيت زندكى و سلامت استفاده مـيشـود. ايـن

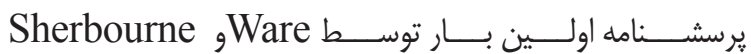
در سال بو 199ر كشور آمريكـا طراحى شده، داراى عس عبارت است و و دو زيرمقياس كلى با نامهاى سلامت جسـمى و سلامت روانى اندازه

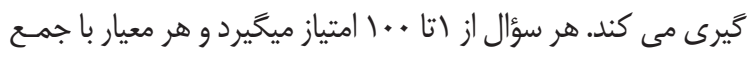

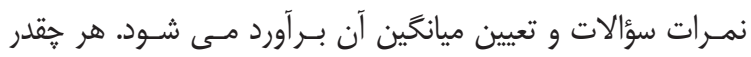

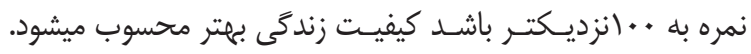

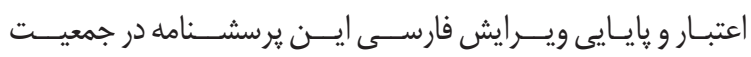
ايرانى توسط منتظرى و همكـاران مـورد تأييـد قرار كرَفته است (بَآ).

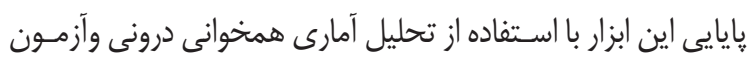

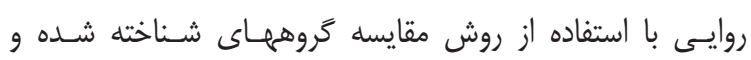

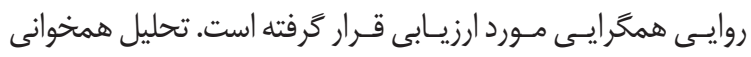

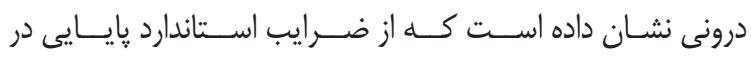

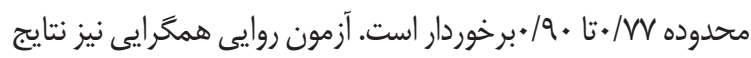

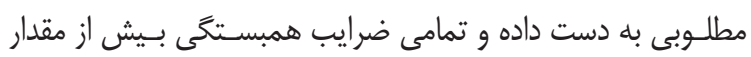

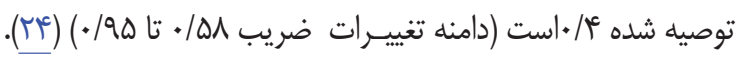

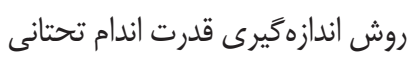

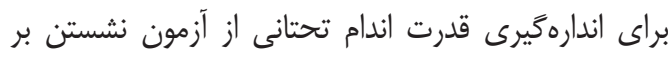
صندلى و ايستادن •rec-) sec Chair Stand Test

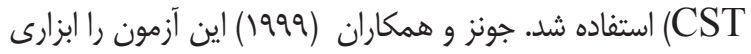

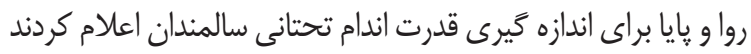

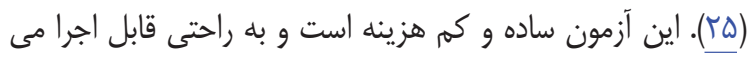

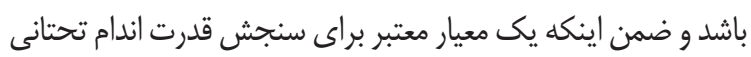

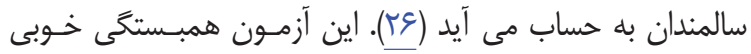

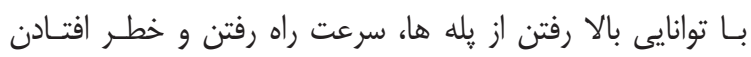

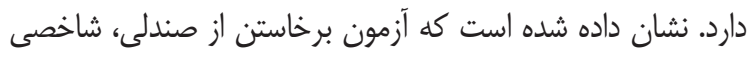

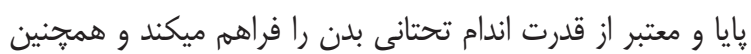
روشى مطمئن و حساس براى تعيين كاهش قدرت مربوط به سن

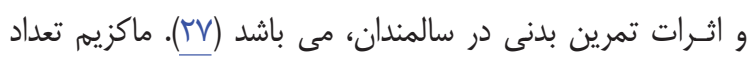

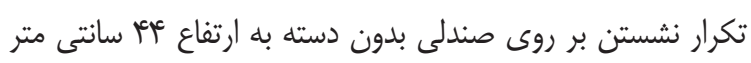

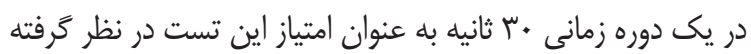
مى شود. تجهيزات اين تست شامل كرنومتر، صندلى با پِشتى قدرتمند

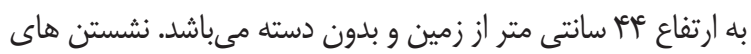

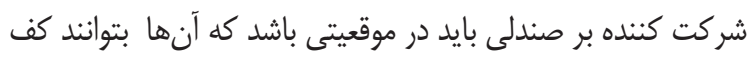

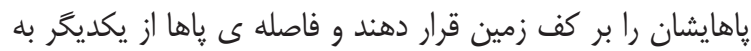

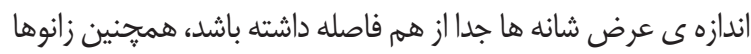


دماى آب، جهت انجام تمرينات آبدرمانى، ه/س - - ه/هّ

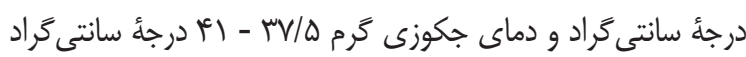
بود. گروه آب درمانى به مدت م هفته و گ جلسه در هفته، تمرينات آب درمانى را انجام دادند و گروه آب درمانى همراه با جكوزى گرمم نيز به مدت ^ هفته تمرينات يكسان با گروه آبدرمانى را انجام دادند با اين تفاوت كه در هر وهله تمرين، به مدت ه دقيقه قبل و بعد از تمرين در جكوزى گرم با دماى • أ درجه، قرار گرفتند. يروتكل كلى تمرينات كه در يزوهش حاضر، مورد استفاده قرار

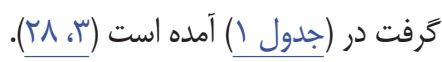

و استراحت كنند. ساعت حركت در نظر گرفته مى شد.

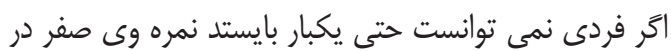
نظر گرفته مى شد. در مرحله بعد اجازه داده شد شركت كننده ها دست هايشان را بر روى ساق هاى خود قرار دهند و يا از وسايل كمكى شان در حركت (واكر وبلجرو..) استفاده كنند. اگر فردى بصورت قابل قبول مى ايستاد، تعداد ايستادن ها در صفحه امتياز دهى بر حسب امتياز تست مورد قبول ثبت مى گرديد

$$
\text { يروتكل تمرينى و روش اجراى تمرين آب درمانى }
$$

\begin{tabular}{|c|c|}
\hline 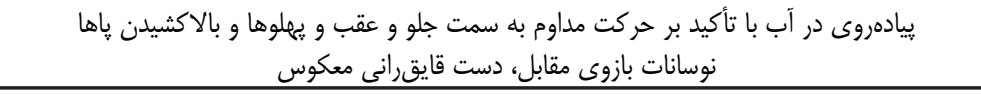 & كرمكردن \\
\hline تمركز بر فلكسور و اكستنسورهاى ران وشانهام / آبداكتور و آداكتور ران و و شانهانه اندانه & كششى \\
\hline 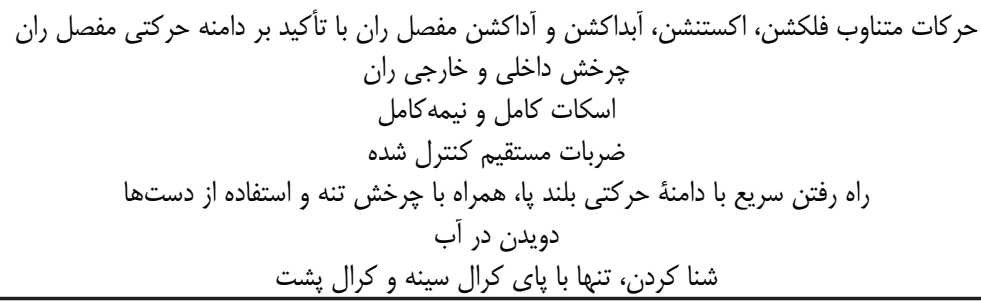 & تقتقيتى و \\
\hline 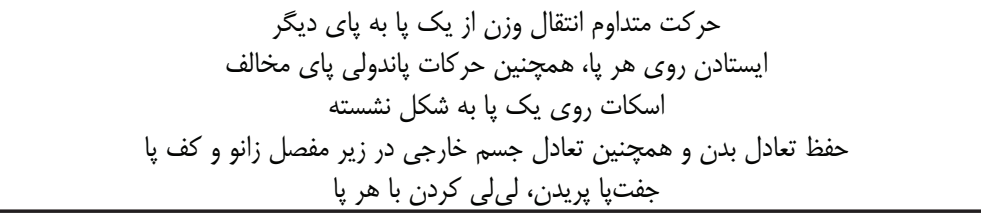 & تعادلى \\
\hline 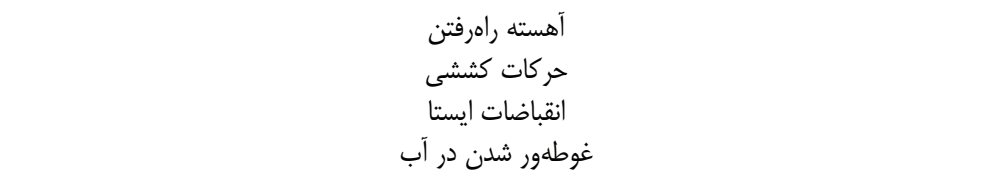 & سرد كردن \\
\hline
\end{tabular}

جدول (: بروتكل كلى تمرينات

كرفته شد.

اين يزوهش توسط گروه تربيت بدنى دانشعاه آزاد اسلامى

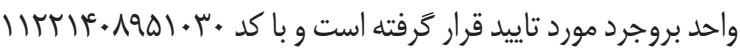
در اين دانشعاه ثبت گرديده است. همرِنين اجراى اين تحقيق با رعايت كامل ملاحظات اخلاقى صورت گرفت، به طورى كه انجام مراحل مختلف تحقيق، با بر رسى سابقه يزشكى و اطمينان از سلامت

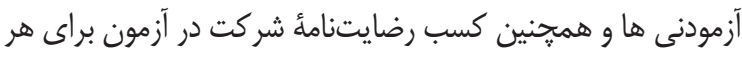

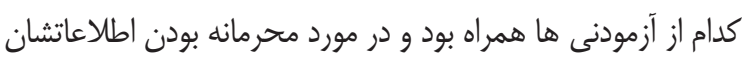

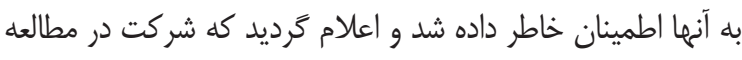
اختيارى است، به طورى كه شركت كنندكًان اجازه خروج از فرآيند يثزوهش را در طول مطالعه دارند.
روشهاى آمارى از آمار توصيفى، شامل ميانخين و انحراف معيار براى نمايش

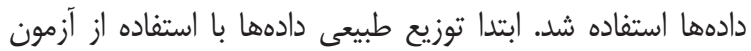
شاييرو ويلك بررسى و يس از مشخص شدن توزيع طبيعى داده ها

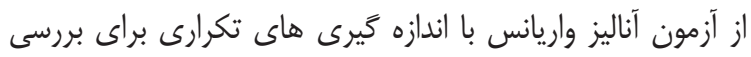
أثار كلى زمان، گروه و متقابل استفاده شد. براى بررسى تغييرات درون گروهى از آزمون تى همبسته استفاده شد. در صورت معنى معنادار شدن تغييرات درون گروهى در هر دو گروه تمرينى، براى بررسى آنى تفاوتها بين دو روش، دلتاهاى دو گروه با آزمون تى مستقل مقايسه

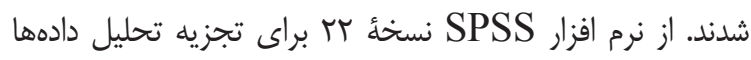
استفاده شد و سطح معنى دارى در كليئ تحليلها (ه+|•> p) در نظر 
درمانى، آب درمانى با جكوزى و كروه كنترل در (جدول r) نشان داده

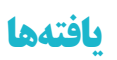

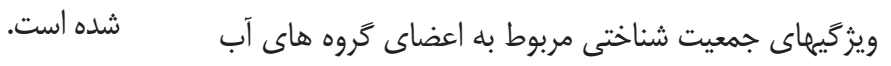

\begin{tabular}{|c|c|c|c|}
\hline درصد & 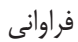 & \multicolumn{2}{|l|}{ متغير } \\
\hline Tr/A & $\wedge$ & بي سواد & \\
\hline$m / \uparrow^{\top}$ & 11 & 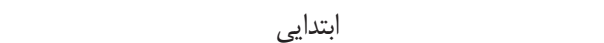 & تحصيالت \\
\hline$r \Delta / V$ & 19 & متوسطه و بالاتر & \\
\hline$V \& / r$ & צ & 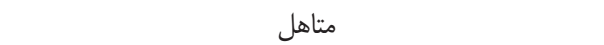 & \\
\hline$r \Delta / \Lambda$ & 9 & مجرد- متاركه و همسر از دست داده & وصعيك ناهل \\
\hline$r$. & $\checkmark$ & 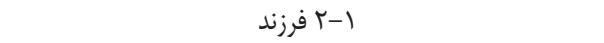 & ..... \\
\hline$\Delta F / T \Lambda$ & 19 & س- ع فرزند & 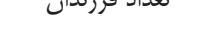 \\
\hline$r a / v$ & 9 & 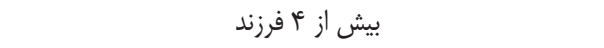 & \\
\hline 4. & r) & مشكلات اسكلتى بالا تنه & مشكلات اسكلت. \\
\hline$t r / \Lambda$ & $\wedge$ & مشكلات اسكلتى پإيين تنه & مسحلات اسحنى \\
\hline$I V / r$ & \& & عدم وجود مشكل اسكلتى خاص & \\
\hline TT/AD & 10 & در كذشته (هسال ييش يا بيشتر) به طور مرتب ورزش مى كردم & \\
\hline $\mathrm{rV} / \mathrm{TQ}$ & r & در كذشته (ه سال ييش يا بيشتر) گَّكاهى ورزش مى كردم & 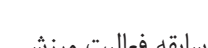 \\
\hline r. & $\checkmark$ & هيج وقت فعاليت ورزشى منظمى نداشتم & سابعه تصايك وررسى \\
\hline
\end{tabular}

اطلاعات توصيفى مربوط به سن، قد و وزن مربوط به مروههاى تجربى و كنترل در (جدول س) نشان داده شده است.

\begin{tabular}{|c|c|c|c|}
\hline كنترل & آبدرمانى و جكوزى & آب درمانى & متغير ها \\
\hline$\varepsilon q / \wedge \pm r / \wedge \varepsilon$ & $V r / r \pm r / l$ & $V \cdot / \Lambda \pm r / q$ & سن (سال) \\
\hline $\mid \Delta \tau / q \pm r / \Delta$ & $|\varepsilon \cdot / \mu| \pm r / q$ & $\mid \Delta S / T \Delta \pm F / V$ & قد (سانتيمتر) \\
\hline$V M / I \pm f / \Delta$ & $V V / r r \pm r / r$ & $V \Delta / \Lambda \pm N / \Gamma$ & وزن (كيلوگرم) \\
\hline
\end{tabular}

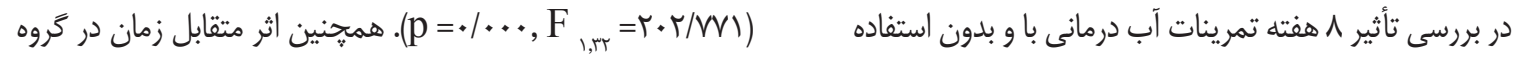

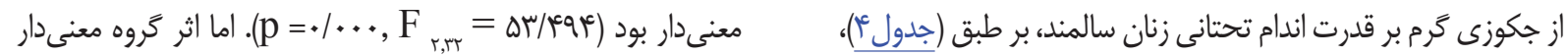

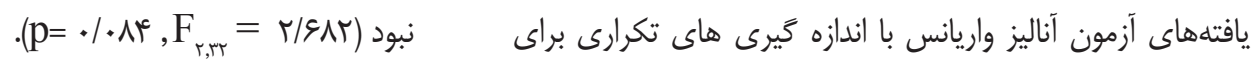
متغير قدرت اندام تحتانى نشان داد كه اثر زمان، معنادار بود الثاني

جدول fُ: نتايج تحليل واريانس با اندازه گيرى هاى مكرر براى بررسى اثرات تعاملى دو متغير زمان و گروه براى قدرت اندام تحتانى

\begin{tabular}{|c|c|c|}
\hline سطح معنادارى p & نسبت F & شاخص \\
\hline$\cdot 1 \ldots$ & $r \cdot T / R M$ & زمان \\
\hline$\cdot 1 \cdot 14$ & r/GAT & كروه \\
\hline $.1 \ldots$ & $\Delta r / F q q^{F}$ & گروه زمان \\
\hline
\end{tabular}

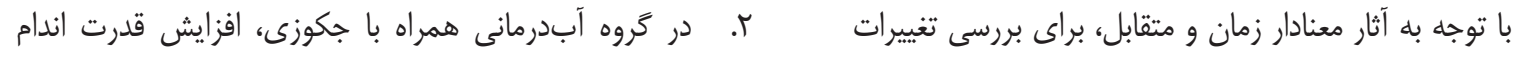

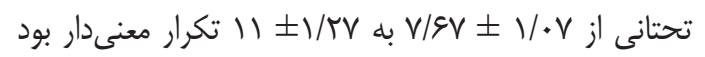
درون گَروهى از آزمون تى وابسته استفاده شد. همانطور كه در جدول

$$
\cdot\left(\mathrm{p}=\cdot / \cdots, \mathrm{t}_{11}=-1 \cdot / \mathrm{v} \& 1\right)
$$
ه و (نمودار ())، نمايش داده شده است، يافتهها نشان داد:

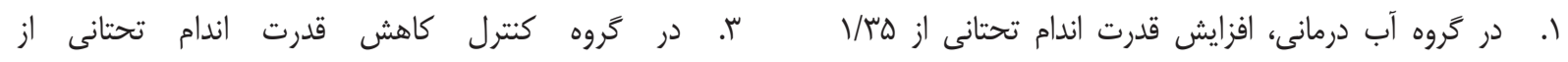
r./

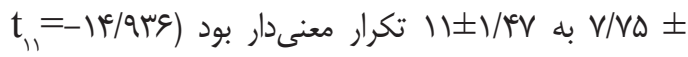

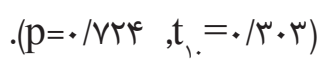

$$
\cdot(\mathrm{p}=\bullet / \cdots,
$$




\begin{tabular}{|c|c|c|c|c|}
\hline Pقدار P P P & T Toاره T & يَ آزمون & ييش آزمون & كروه \\
\hline.$/ \ldots$ & - & $\| \pm 1 / \mathcal{A} V$ & $V / V \omega \pm 1 / \Gamma \Delta$ & آب درمانى \\
\hline.$/$ & $-1 \cdot / V \& 1$ & $\| \pm 1 / r V$ & $V / q V \pm V / \cdot V$ & آب درمانى با جكوزى \\
\hline . /VYY & (r. & $N / T V \pm 1 / \Delta \Delta$ & $N / r q \pm 1 / \cdot r$ & كنترل \\
\hline
\end{tabular}

$P \leq \cdot / \cdot \Delta$

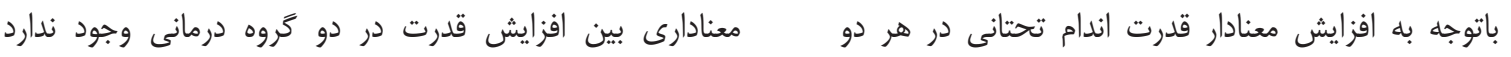

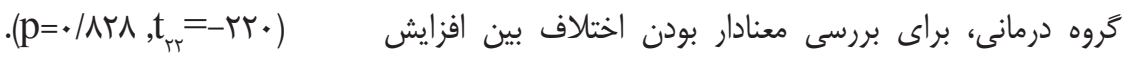

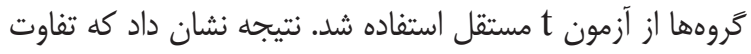

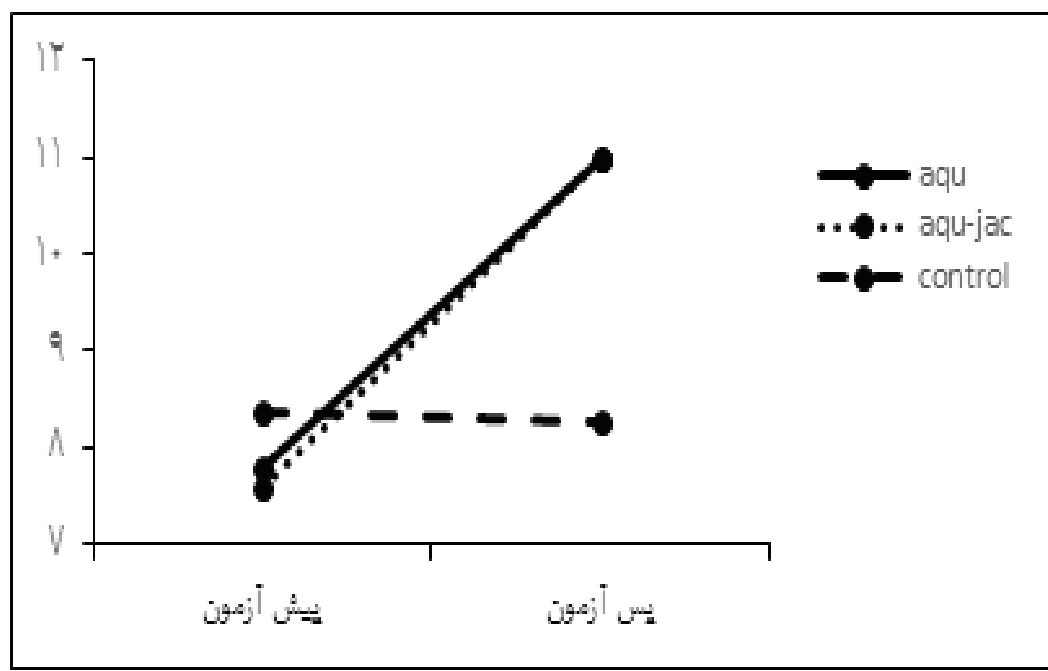

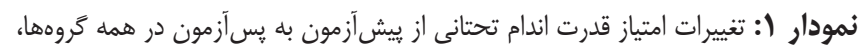

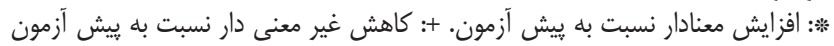

در بررسى تأثير ^ هفته تمرينات آب درمانى با و بدون طبق (جدول و)، يافته هاى آزمون واريانس با اندازه هاى تكرارى

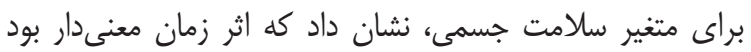

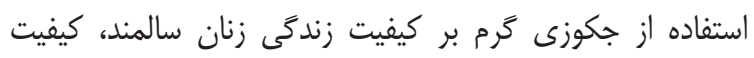

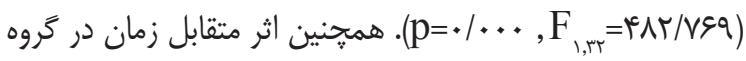
زندگى به دو قسمت سلامت جسمى و سلامت روانى تقسيم ركان معنى دار بود ( مى شود كه در بررسى تأثير 1 هفته تمرينات آب درمانى

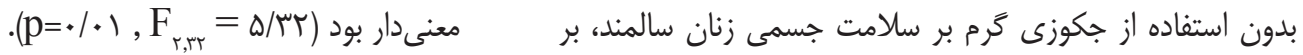

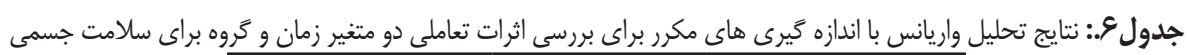

\begin{tabular}{|c|c|c|}
\hline سطح معنادارى p & Fسبت F F & شاخص \\
\hline.$\%$ & FAT/VGQ & زمان \\
\hline $.1 \cdot 1$ & Q/T T & كروه \\
\hline.$/ \ldots$ & $\mid r N / F V V^{C}$ & كروه زمان \\
\hline
\end{tabular}

- در گروه آب درمانى همراه با جكوزى، افزايش سلامت

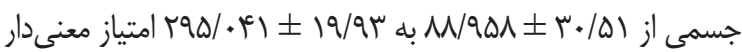

$$
\text { بود ( } 1 \mathrm{c})
$$

- در گروه كنترل كاهش سلامت جسمى از

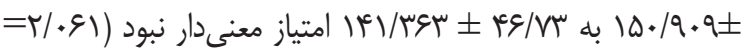

$$
\cdot\left(\mathrm{p}=.1 .99, \mathrm{t}_{1}\right. \text {. }
$$

با توجه به آثار معنىدار زمان و متقابل، براى بررسى تغييرات

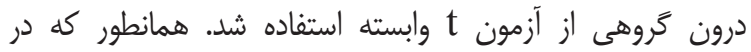

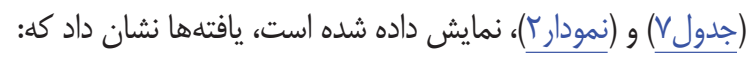

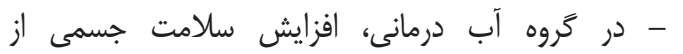

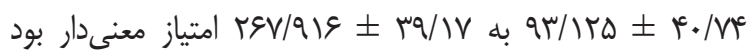
$\cdot\left(\mathrm{p}=\cdot / \cdots, \mathrm{t}_{11}=-1 \mathrm{l}-/ \mathrm{N}^{\mathrm{e}} \mathrm{V}\right)$ 
جدول V: نتايج آزمون تى وابسته براى سلامت جسمانى در كروه هاى كنترل و كروه آزمايش

\begin{tabular}{|c|c|c|c|c|}
\hline مقدار P P & T T T T T & ֶِ آزمون & يیش آزمون & گروه \\
\hline.$/ \ldots$ & $-I T / V E V$ & $r \varepsilon V / q) \& \pm r q / / V$ & $q r / / r \Delta \pm r \cdot / V T^{c}$ & آب درمانى \\
\hline 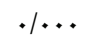 & -rQ/ą) & $r q \Delta / \cdot+1 \pm 19 / q 4$ & $M N / ৭ \Delta \Lambda \pm r \cdot / \Delta)$ & آب درمانى با جكوزى \\
\hline .1 .99 & $r / .91$ & 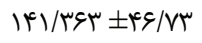 & $10 \cdot / 9 \cdot 9 \pm r \wedge / 9 r$ & كنترل \\
\hline
\end{tabular}

\section{$\mathrm{P} \leq 0 / 05$}

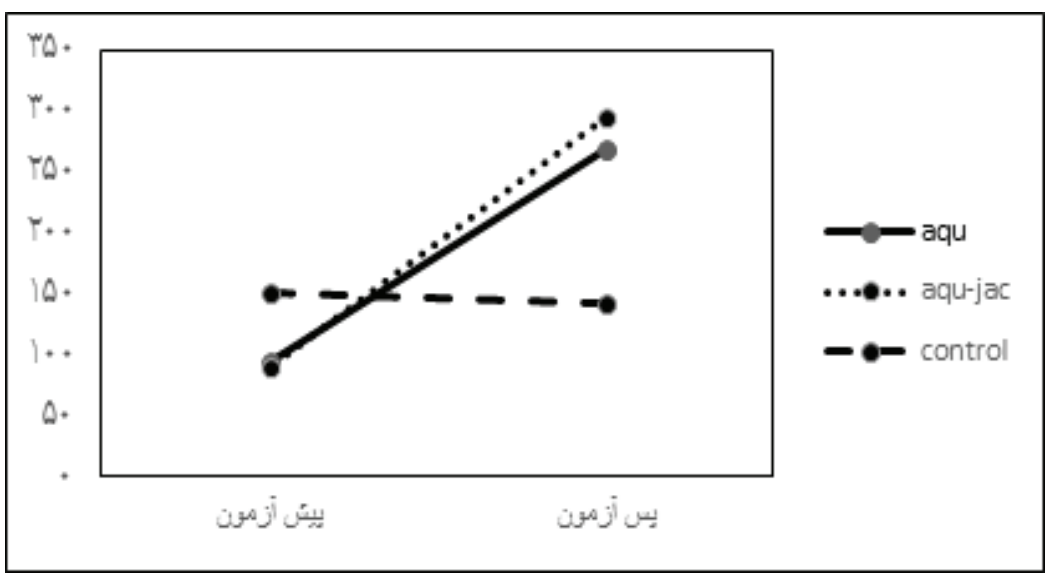

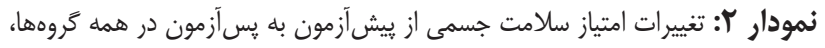

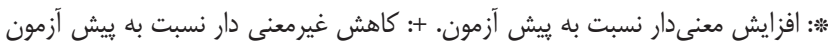

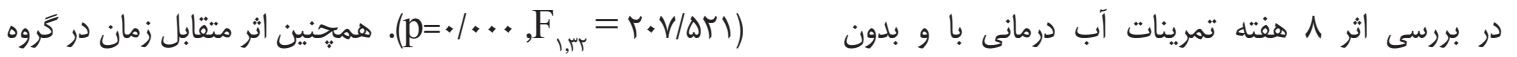

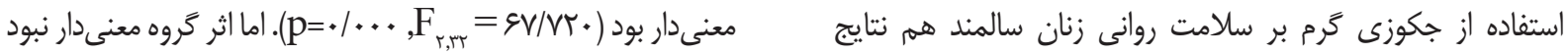

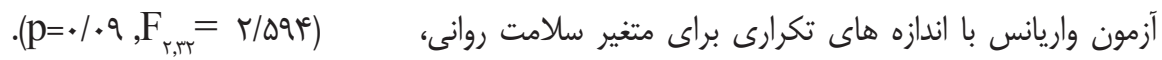

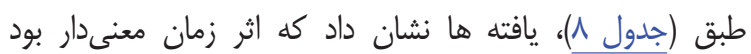

جدولم: نتايج تحليل واريانس با اندازه كَيرى هاى مكرر براى بررسى اثرات تعاملى دو متغيير زمان و كروه براى سلامت روانى

\begin{tabular}{|c|c|c|}
\hline p سطح معنادارى & Fسبت F ن & شاخص \\
\hline $.1 \ldots$ & $r \cdot V / \Delta T /$ & زمان \\
\hline .1 .9 & r/DQF & كروه \\
\hline.$/ \ldots$ & SV/VT. & كروه زمان \\
\hline
\end{tabular}

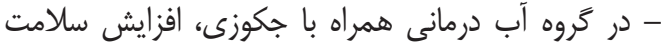

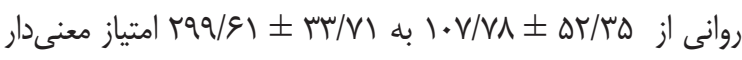

$$
\text { بود (p) }
$$

- در كروه كنترل كاهش سلامت روانى از

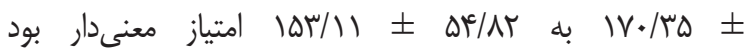

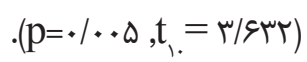

با توجه به آثار معنىدار زمان و متقابل، براى بررسى تغييرات

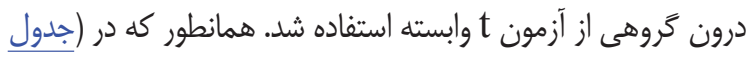

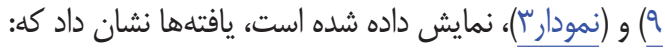

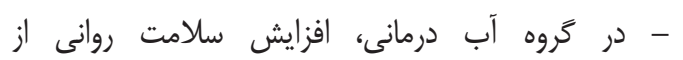

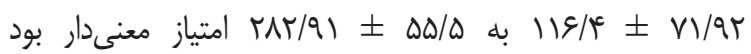
.$\left(\mathrm{p}=\cdot / \cdots, \mathrm{t}_{11}=-\mathrm{N} / \mathrm{Q \Delta T}\right)$

\begin{tabular}{|c|c|c|c|c|}
\hline مقدار P & Tآماره T & پِس آزمون & ييش آزمون & كروه \\
\hline.$/ \ldots$ & $-N / q \Delta \mu$ & $r \Lambda T / q$ & $\| 1 / 8 / 4 \pm V$ & \\
\hline$\cdot / \ldots$ & $-|\Delta| \cdot \pi r$ & rq9/9) & $1 \cdot V / v \wedge \pm$ & 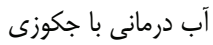 \\
\hline$\cdot / \cdot \Delta$ & Tr/ T/M & $\mid \Delta \Psi / \| \pm \Delta F / A r$ & $\mid V \cdot / \Gamma \Delta \pm F \Delta / A T$ & كنترل \\
\hline
\end{tabular}

جدوله: نتايج آزمون تى وابسته براى سلامت روانى در كروه هاى كنترل و كروه آزمايش

$\mathrm{P} \leq 0 / 05$ 
آزمون t مستقل استفاده شد. نتيجه نشان داد كه تفاوت معنىدارى

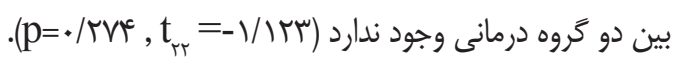

باتوجه به افزايش معنىدار سلامت روانى در هر دو كروه درمانى براى بررسى معنىار بودن اختلاف بين افزايش گروهها از دراز

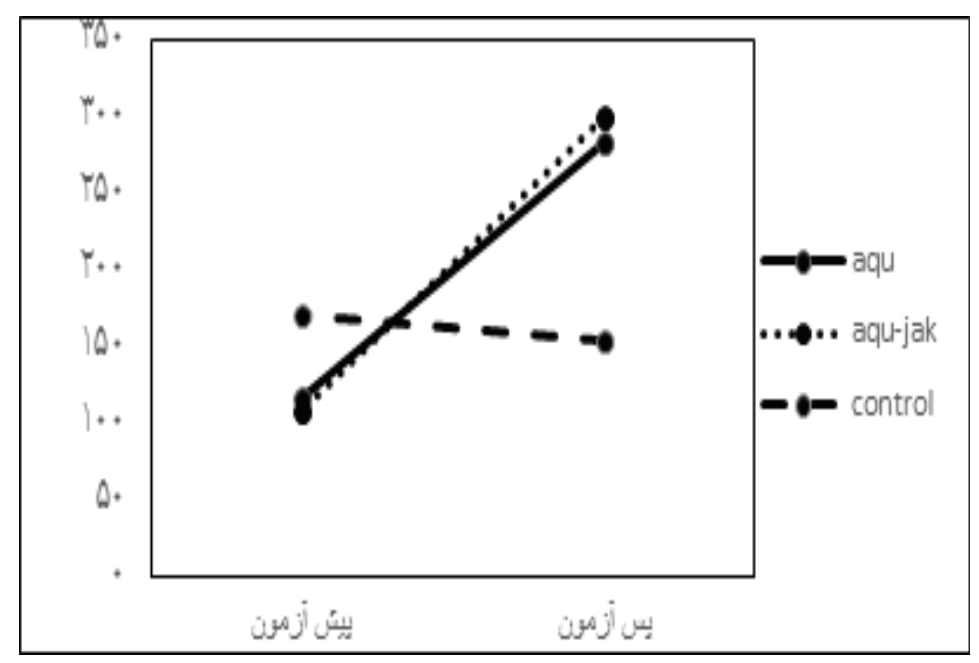

نمودار سّ: تغييرات امتياز سلامت روانى از يبش آزمون به يَس آزمون در همه كروهها،

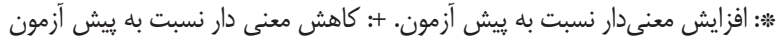

سالمندان ضعف در تبادل اطلاعات حسى-حركتى و كاهش هماهنخى درون عضلانى و بين عضلانى موجب تنزل قدرت عضله تها

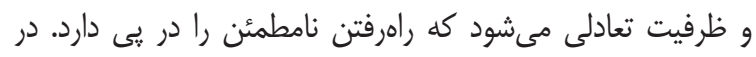
نتيجه سالمندى، دوره افزايش احتمال بروز مشكلات حاد ناشى از

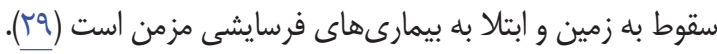
ضعف عضلانى در دور كنندهاى ران، باز كنندهها و و خمكنندهاى زانو و عضلات دورسى فلكسور مج ها، با خطر افتادن دان هنكام حركت و راه رفتن ارتباط دارد. براى راه رفتن به همكارى كروههاى مختلف عضلانى نياز است و شدت حركتهاى خهم شدن،

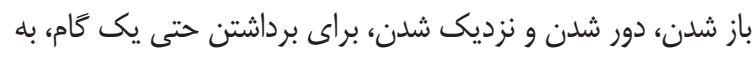
قدرت عضلانى وابسته است. قدرت عضلانى كافى سبب سهولت در برد راه رفتن مى شود و در مقابل، كاهش قدرت عضلانى به ويزّه در دوره

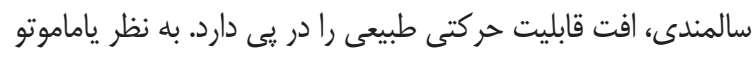

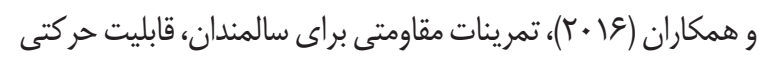

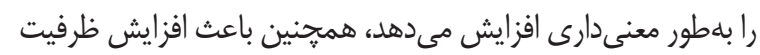
تمرينى و افزايش قدرت عضلانى مىشود و نيز قابليت و بهبود قابليت

حركتى در افر اد ميانسال و سالمند را به دنبال دارد (•بّ).

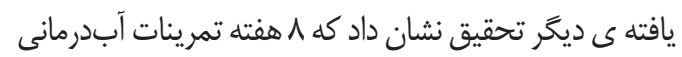
همراه با جكوزى و يا بدون جكوزى، باعث بهبود معنىدار كيفيت

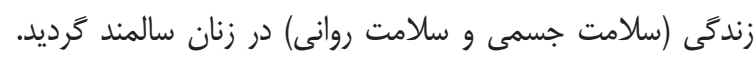

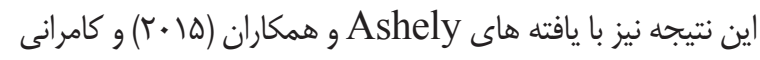

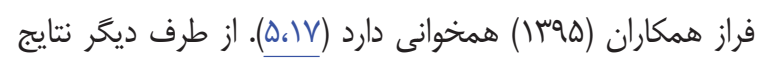

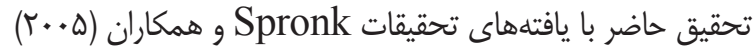

در اين يزوهش تأثير 1 هفته تمرينات آبدرمانى باو بدون

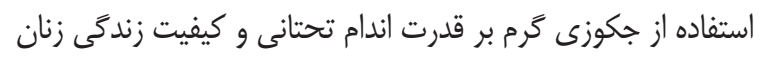

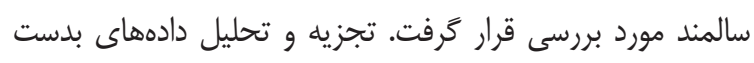

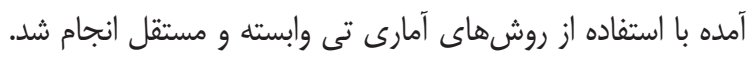

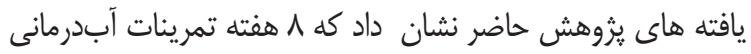
باو بدون استفاده از جكوزى باعث بهبود معنادار قدرت اندام تحتانى نافي

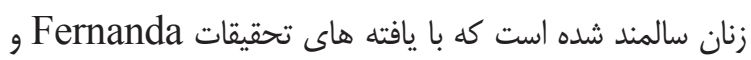

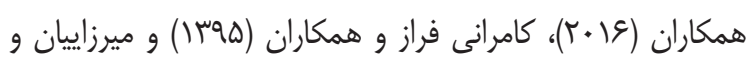

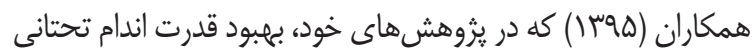

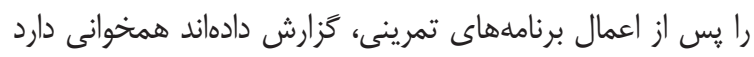
(D.19.5.)

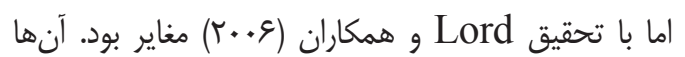
در تحقيق خود گزارش دادند كه در طول r ب هفته تمرين آبى يك

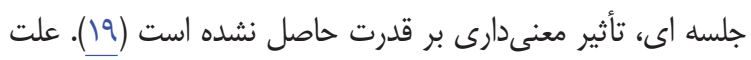

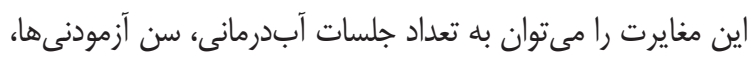

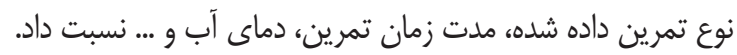
قدرت يا توانايى مقاومت عضله در برابر يك نيروى (اغلب)

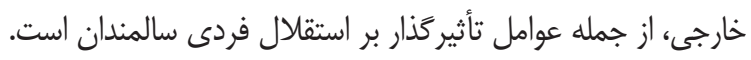

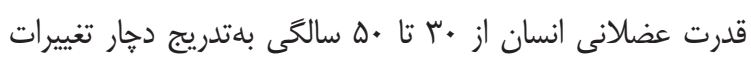
فرسايشى مىشود. شتاب شيب نزولى قدرت در دها ششم زندگى إنى ها درصد و در دها هشتم حدود •ب درصد افزايش مى فيابد. در 
مىتوان جنين توضيح داد كه خون كيفيت زندگى به عوامل جسمانى،

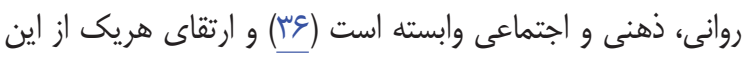

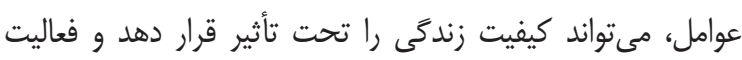

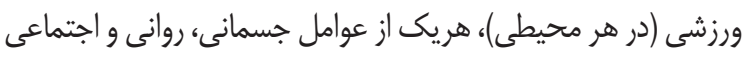
را تحت تأثير قرار مىدهد. از جمله ساز كارهاى روانى اثرات ورزش أشى

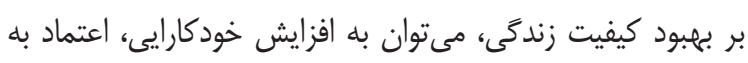

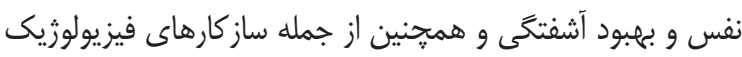
به افزايش نورابى نفرين، تغيير در سنتز و متابوليسم سرتونين و

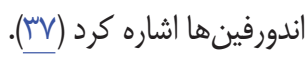

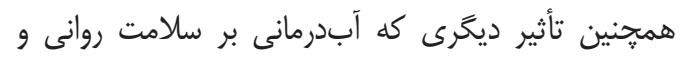

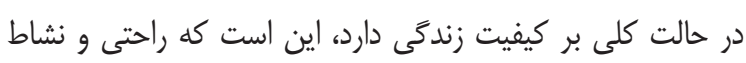

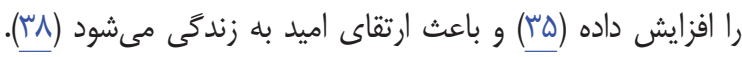
عواملى مانند بازنشستخى، تنهايى، احساس بيهودگى و ناتوانى در

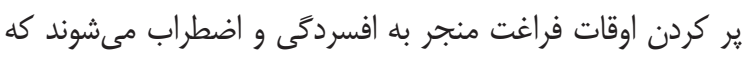

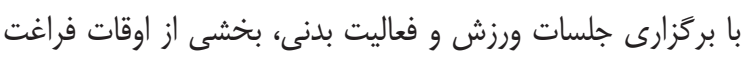

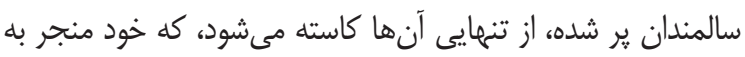

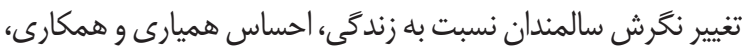

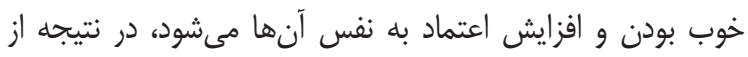

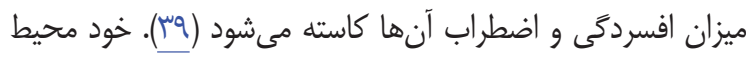
آب نيز باتوجه به خواصى كه دارد باعث آرامش روحى و روانى خاصى إنى

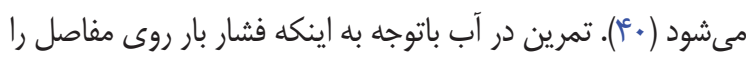

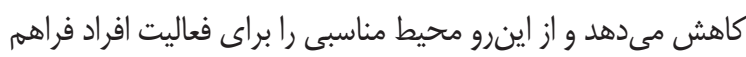

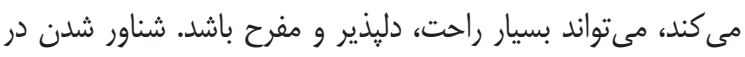

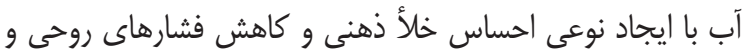
روانى و تا حدودى كاهش ترشح إيىنفرين، مىتواند روى مشكلات إنات

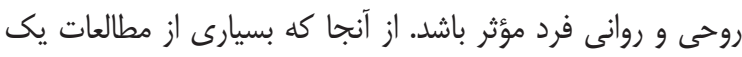
رابطه مثبت بين فعاليت جسمانى و سلامت روانى را نشان دادهاند،

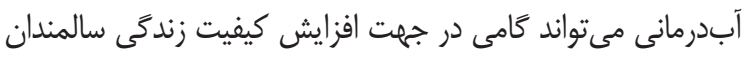

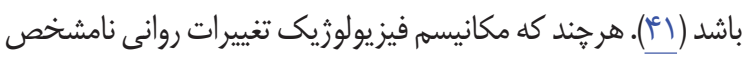

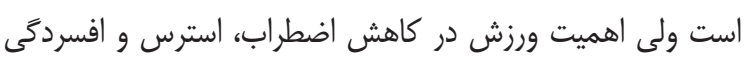
كاملاً روشن و واضح است.

از محدوديت هاى اين يزوهش مى توان به ناتوانى در كنترل

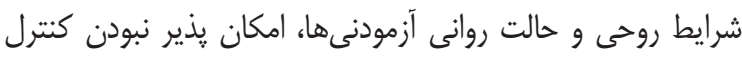

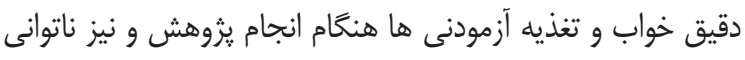

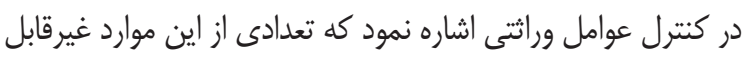
كنترل بودند ولى با ارائه راهنمايى هاى لازم در مورد كنترل تغذيه و خواب، سعى كرديد تا حدودى محدوديت هاى موجود كنترل شود.
مغاير است (1)()، كه علت احتمالى اين مغايرت را مىتوان به تفاوت

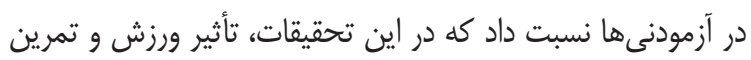

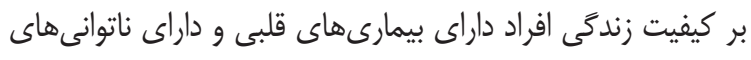

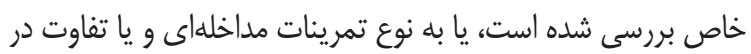
نوع ابزار استفاده شده جهت ارزيابى كيفيت زندگى مرك، مربوط دانست.

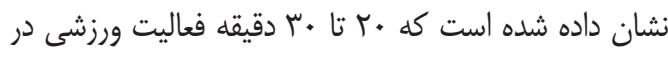
روز با شدت متوسط، به كم كردن محدوديتهاى فعاليتى، افزايش

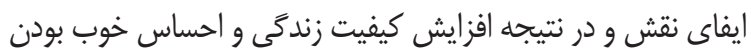
كمك بسيارى مى كند (آّ). بر اساس مطالعات انجام شده، داشتن

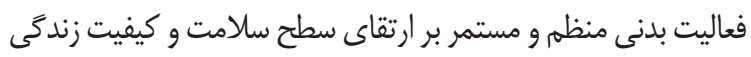

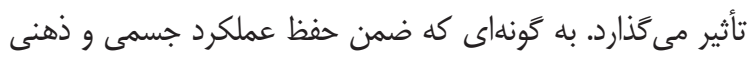

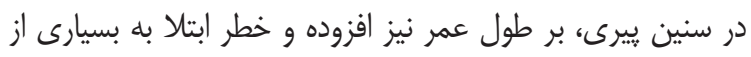
بيمارى هاى مزمن را كاهش مىدهد. يكى از ويزَى ها و فوايد محيط آبى، شناورى آن است. طبق مهد قوانين ارشميدس يك شىء يا جسمى كه در آب قرار مى گئيرد،

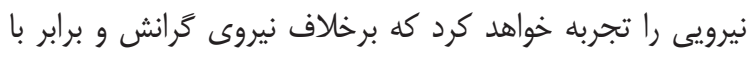
ميزان آبى كه توسط جرم جسم جابهجا مىشوده، مى بـاشد. حمايت

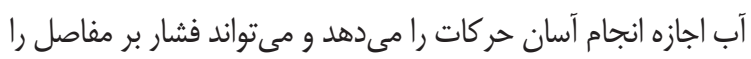

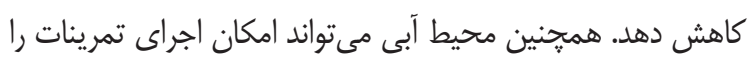
در موقعيتهايى فراهم كند كه اجراى آن در خشكى به به دليل فقاند الندان

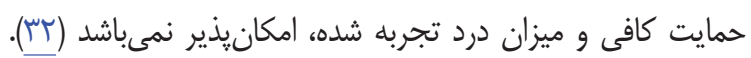

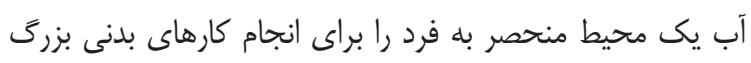

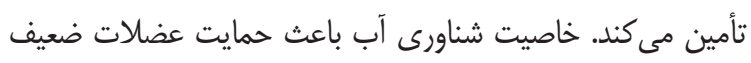
يا آسيب ديده مىشود. آب باعث حذف فشار (بار) از روى مفاصل

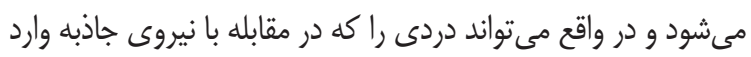

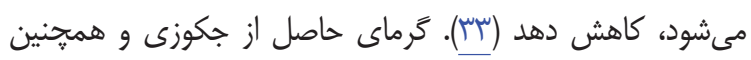

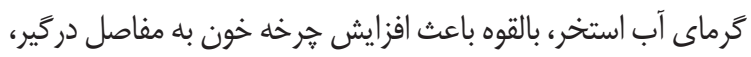
ريلكسى عضلات و كاهش موقتى درد شود (عبّ). به علاوه فعاليت

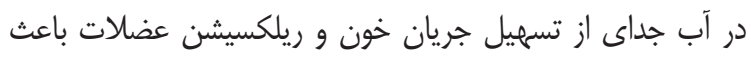

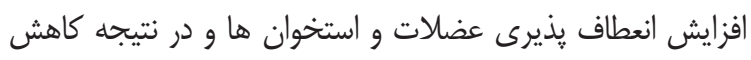

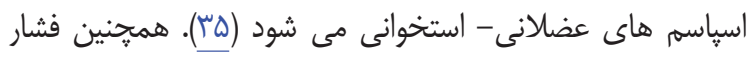

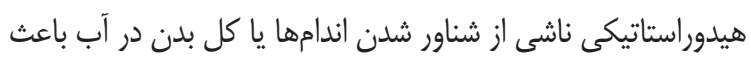

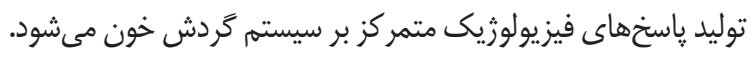

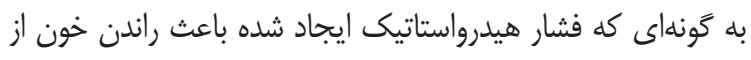

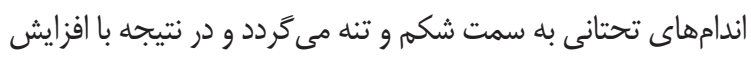

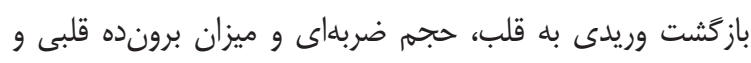
خونرسانى به اندامها را افزايش مى دهد (هـَ).

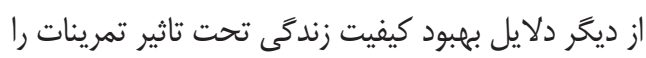




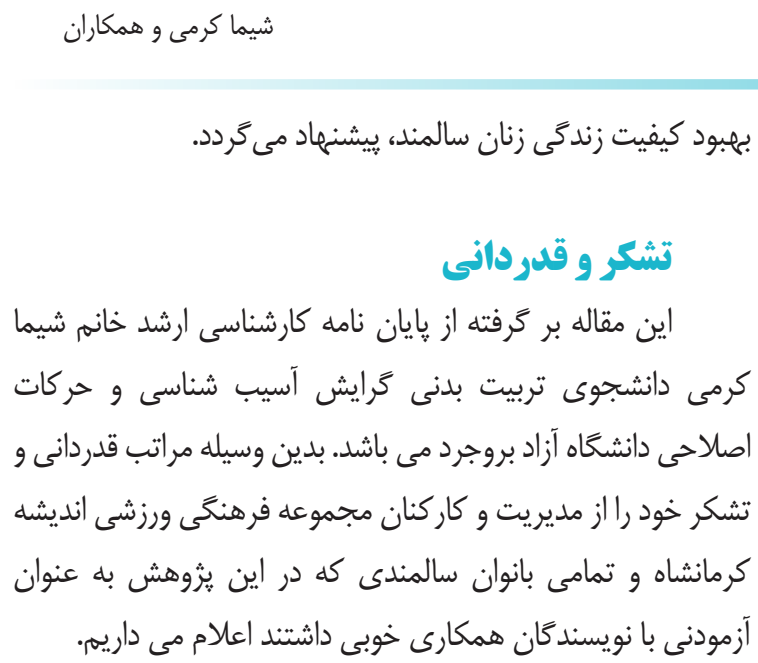

\section{References}

1. Zabihi A, Jafarianamiri SR, Aziznejad P, Hosseini SR, Bijani A. Elderly Falling in houses and related factors. Journal of Babol University of Medical Sciences. 2013; 15 (5):95-101.

2. Katsura Y, Yoshikaw T, Veda SY, Usai T, Sotobayashi D, Nakao $\mathrm{H}$,et al. Effect of aquatic exercise training using water resistance equipment in elderly. Eur J Apple Physiol. 2010; 108 (5):959-64.

3. Resende SM, Rassi CM. Effects of hydrotherapy in balance and prevention of falls among elderly women. Brazilian Journal of Physical Therapy. 2008 Feb; 12 (1):57-63.

4. Negaresh R, Ranjbar R, Habibi A, Gharibvand M M. The relationship between muscle volume and strength and some factors associated with sarcopenia in old men compared with young men. Zanko journal of Medical Sciences. 2016; 17 (54): 23- 34.

5. Kamranifaraz N, letafatkar A, Javdaneh N. The effect of a Compound exercises in the water on muscle strength, flexibility, and quality of life of elderly women 60- 70 years old in thran. Bpums. NJV 2016; 3 (9): 24-37.

6. Adib M. Evaluation of disability and its related factors in elderly Kashan. Iranian Journal of Ageing. 2008; 3 (8): 547-55.

7. Heydarnejad M, Hassanpour DA, Solati DK. Factors affecting quality of life in cancer patients undergoing chemotherapy. African Health Sciences. 2012; 11 (2): 266-70.

8. Burack OR, Weiner AS, Reinhardt JP, Annunziato RA. What matters most to nursing home elders:
در نتيجه گَيرى كلى برآمده از يافته هاى اين يزوهش مى كى

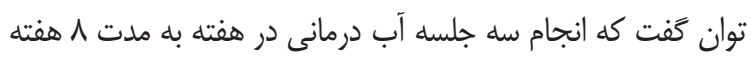
مى تواند با افزايش معنادار قدرت عضلانى اندام تحتانى و كيفيت زندگى در زنان سالمند همراه باشد. همجنين، انجام همين يروتكل

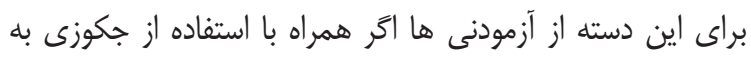

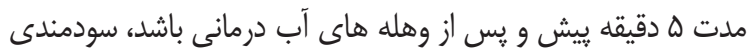
مشابهى دارد و تفاوت معنادارى بين آثار دو روش ديده نمى شودى شود. لذا استفاده از آب درمانى براى افزايش قدرت عضلانى اندام تحتانى و

quality of life in the nursing home. Journal of the American Medical Directors Association. 2012; 13 (1):48-53.

9. Landi F, Liperoti R, Fusco D, Mastropaolo S, Quattrociocchi D, Proia A, et al. Prevalence and risk factors of sarcopenia among nursing home older residents. Journals of Gerontology Series A: Biological Sciences \& Medical Sciences. 2012; 67(1):48-55.

10. Pereira F D, Batista W O, Fuly P D S C, Junior E D D A, Silva E B D. Physical activity and respiratory muscle strength in elderly: a systematic review. Fisioter Mov. 2014; 27 (1): 129-39.

11. Geirsdottir O G Arnarson A, Ramel A, Briem K, Jonsson P V, Thorsdottir L. Muscular strength and physical function in elderly adults 6-18 months after a 12-week resistance exercise program. Scandinavian journal of Public Health. 2015; 43 (1):76-83.

12. Arnold CM, and Faulkner RA: The Effect of Aquatic Exercise and Education on Lowering Fall Risk in Older Adults With Hip Osteoarthritis, Journal of Aging and Physical Activity. 2010; 18:245-260.

13. Laura I. Your guide to: Physical therapy. Total rehabilitation. 2008; 1 - 5.

14. Yadegarpour M, Shojaedin SS, Sadeghi H. Effect of aquqtic endurance training program on static and dynamic balance and lower limb strength in elderly male veterans. Journal of Research in Rehabilitation Sciences (JRRS). 2012; 8 (3):44253.

15. Ruoti, R. G., Morris, D. M., \& Cole, A. J. (Eds.). 
Aquatic rehabilitation. Lippincott Williams \& Wilkins.2004.

16. Fernanda de Mattos, Neiva Leite, Arthur Pitta, Paulo Cesar Barauce Bento. Effects of aquatic exercise on muscle strength and functional performance of individuals with osteoarthritis: a systematic review. Rev bras reumatol; 2016; 56 (6):530-542.

17. Ashely N Frohman, Darin T okuda, Shin Beh, Katherine Treadaway, Caroline Mooi, Scott L Davis, Anjali Shah, Teresa C Frohman, Elliot $\mathrm{M}$ Frohman. Aquatic training in MS: neurotherapeutic impact upon quality of life. Ann Clin Transl Neurol; 2015; 2 (8): 864-872.

18. Spronk, S., Bosch, J. L., Veen, H. F., den Hoed, P. T., \& Hunink, M. M. Intermittent Claudication: Functional Capacity and Quality of Life after Exercise Training or Percutaneous Transluminal Angioplasty - Systematic Review 1. Radiology, 2005; 235 (3), 833-842.

19. Lord, S. R., Matters, B., St George, R., Thomas, M., Bindon, J., Chan, D. K \& Haren, L. The effects of water exercise on physical functioning in older people. Australasian Journal on Ageing, 2006; 25 (1), 36-41.

20. Mirzaeian E, Kazemzade Y, Sokhangooei Y. Effect of 8 weeks of water exercises on static and dynamic balance, walking, strength of the lower extremity of elderly women. The first national conference on sport science developments in the field of health, prevention and championship. 2016 .https://www.civilica.com/PaperPESSO01-PESSO01_037.html.

21. Lim KO, Lee DY, Shin WS. The effects of a warm whirlpool bath on pain and stiffness of patients with chronic stroke induced knee osteoarthritis. Journal of physical therapy science. 2013; 25 (7): 873-5.

22. Becker BE. Aquatic therapy: scientific foundations and clinical rehabilitation applications. PM\&R. 2009 Sep 30;1(9):859-72.

23. Ganesh V D, Sandeep S T, Sonali B D, Atul S B, Avinash P T, Rajendra N P. Hydrotherapy A New Trend in Disease Treatment. IJSRM Journal. 2016; 5 (2):117- 135.

24. Montazeri A, Goshtasebi A, Vahdaninia MS.
[Translation, validity and reliability measurement of Sf36 questionnaire Persian version]. Payesh Journal. 2006; 5 (1): 49-56.

25. Jones, C. J., Rikli, R. E., \& Beam, W. C. A 30-s chair-stand test as a measure of lower body strength in community-residing older adults. Research quarterly for exercise and sport, 1999; 70 (2), 113-119.

26. Ghaeeni, S. Amirkhani, F. The Effect of Increasingly Rehabilitation Program on the Growth Growth of the Extremity of the Elderly With Arthritis, after knee replacement. Sports Medicine. 2015; 7 (1). 69- 84.

27. Sadeghi H. Yadegarpoor M. Ghasempoor H. Shojaaddin S. The effect of eight weeks of combined water stress training on the strength of the lower extremity and walking speed of elderly men. Elderly journal. 2011; 7 (27): 59- 66.

28. American Parkinson Disease Association. Aquatic Exercise. An Exercise Program for people with Parkinson's Disease. Edited By Julie See \&Nokomis, FL. 2008; 16- 25.

29. Faulkner, J. A., Larkin, L. M., Claflin, D. R., \& Brooks, S. V. Age-related changes in the structure and function of skeletal muscles. Clinical and Experimental Pharmacology and Physiology, 2007; 34 (11), 1091-1096.

30. Yamamoto Sh, Hotta K, Ota E, Mori R MD, Matsunaga A. Effects of resistance training on muscle strength, exercise capacity, and mobility in middle-aged and elderly patients with coronary artery disease: A meta-analysis. Journal of Cardiology, 2016; 68 (2), 125-134.

31. Rowlinson J. Safe Exercise for the Elderly. Available at: http://www.safesport.co.uk/ WaterSports Category.html/Updated: 2010.

32. Sarvari, F. Effect of hydrotherapy in functional status of multiple sclerosis patients. Ferdowsi University Mashhad, 2012; (3), 23-27.

33. Arabnarmi, Z. Effect of hydrotherapy in elderly gaite, Ferdowsi University Mashhad, 2010; 1, 89- 96.

34. Ghaffari S, Ahmadi F, Nabavi SM, Memarian R, Kazemnejad A. The effect of progressive muscle relaxation technique daily living activities in patients with multiple sclerosis, J Rehabilitation. 
2008; 2 (30): 73-80

35. Sadeghi, H., \& Alirezaee, F. The effect of a water exercise program on static and dynamic balance in elderly women. 2008.

36. Acree, L. S., Longfors, J., Fjeldstad, A. S., Fjeldstad, C., Schank, B., Nickel, K. J., ... \& Gardner, A. W. Physical activity is related to quality of life in older adults. Health and quality of life outcomes, 2006; 4 (1), 1.

37. Shahrjerdi S, Shavandi N, Sheikh-Hoseini R, Shahrjerd S. The effect of strengthening and endurance training on metabolic factors, quality of life and mental health in women with type $\Pi$ diabetes. J Shahrekord Univ Med Sci; 2010; 12 (3):85-93.

38. Sugano, A., Wakabayashi, H., Aoba, T., \& Nomura, T. Physical and psychological changes after participation of 8-week water exercise in chronic low back patients; 12-month follow-up. Biomechanics and Medicine in Swimming IX. Publications de l'Universite de Saint-Etienne, 2003; 9, 579-84.

39. Payne, V. G., \& Isaacs, L. D. Human motor development: A lifespan approach. McGrawHill.2nd ed. 2008.

40. Elavsky S, McAuley E, Motl RW, Konopack JF, Marquez DX, Hu L, et al. Physical activity enhances longterm quality of life in older adults: Efficacy, esteem, and affective influences. Annals of Behavioral Medicine. 2005; 30 (2): 138-45

41. Sadeghi H. Effect of one episode hydrotherapy in elderly women. J Elder Iran; 2007; 2 (6):74-83. 